Cornell University Law School Scholarship@Cornell Law: A Digital Repository

$2-1985$

\title{
Anti-Trust and Economic Theory: Some Observations from the US Experience
}

George A. Hay

Cornell Law School, george.hay@cornell.edu

Follow this and additional works at: http://scholarship.law.cornell.edu/facpub

Part of the Antitrust and Trade Regulation Commons, and the Law and Economics Commons

\section{Recommended Citation}

Hay, George A., "Anti-Trust and Economic Theory: Some Observations from the US Experience" (1985). Cornell Law Faculty Publications. Paper 1152.

http://scholarship.law.cornell.edu/facpub/1152

This Article is brought to you for free and open access by the Faculty Scholarship at Scholarship@Cornell Law: A Digital Repository. It has been accepted for inclusion in Cornell Law Faculty Publications by an authorized administrator of Scholarship@Cornell Law: A Digital Repository. For more information, please contact jmp8@cornell.edu. 


\title{
Anti-Trust and Economic Theory: Some Observations from the US Experience
}

\author{
G.A. HAY*
}

\section{INTRODUCTION}

Recent developments in US anti-trust can be characterised as reflecting the uneasy interaction of two quite separate phenomena: first, the increased emphasis on economic analysis as the overriding organising principle of antitrust policy and on economic efficiency as the primary (perhaps only) relevant goal for anti-trust; second, the long-standing reluctance of the federal judiciary to involve itself in any substantive economic analysis, and the preference, instead, for simple rules of thumb or 'pigeon holes' to sort out lawful from unlawful conduct. ${ }^{1}$ The result has been that while economics has played a major role, it has not influenced American anti-trust as thoroughly or as uniformly as might have been imagined; rather the extent and the nature of its influence have depended on the degree to which the relevant economics could be reduced to the kind of simple rules or pigeon holes that the judiciary favours. The present paper will illustrate that theme, first by reporting on the two developments separately and then by illustrating their joint influence with reference to two important areas of American antitrust: predatory conduct and so-called vertical restraints. Finally, a contrast will be made between judicial development in those two areas and recent American merger policy which, it is argued, is carried out largely independently of the judiciary, and hence the opportunities for economics to influence the process are less inhibited by the judicial reluctance to undertake extensive economic analysis.

\footnotetext{
*George Hay is Professor of Law and Economics at Cornell University, Ithaca, New York and is currently a Visiting Fellow at the Centre for Socio-Legal Studies, Wolfson College, Oxford.
}

' This theme is developed in greater detail in Hay (1984). 
The current emphasis by the Reagan administration on economic efficiency as the primary goal of anti-trust policy is by now well known. William Baxter, Reagan's first appointee to head the Justice Department's Antitrust Division, was outspoken on the subject, both in his former career as a Stanford University Law Professor and during his three year tenure as head of the Antitrust Division. But while the emphasis on economics clearly reached new heights under the Reagan administration, the trend dates at least to the mid-1960s, when Donald Turner, both a lawyer and a PhD in economics, headed the Division.

Two factors can be identified that have caused the trend to accelerate in recent years. First is the increasing literacy of American law graduates in economics. For reasons having little to do with anti-trust, economics became an increasingly popular major among American college students during the 1960s and 70s. Since law school in America follows the undergraduate degree, growing numbers of American students came to law school with extensive prior education in economics. Moreover, most major law schools were in the process of adding one or more economists to their faculties, thereby providing further opportunity for students to become firmly grounded in economics. With a larger number of lawyers feeling comfortable with economics, the resistance to incorporating economic ideas into legal analyses diminished.

A parallel phenomenon was the increased interest on the part of American economists in policy questions relating to anti-trust law. For reasons partly of intellectual curiosity and partly related to the money that could be earned from offering 'expert' advice and testimony in anti-trust cases, excellently trained economists drifted from other branches of economics to industrial organisation (the branch of economics most closely related to anti-trust). Equally importantly, the economists began to publish in law journals, converting the formidable mathematical language of economic theory into something approaching intelligible English. (There were still some diagrams, but the increased training of lawyers in economics made that less of a problem than it would have been twenty years before.)

\section{ECONOMICS AND THE JUDICIARY}

In light of the above developments, it might seem that the way would be cleared for the complete take-over of American anti-trust by economic theory. But a second factor was operating which would serve both to retard the influence of economics to some extent, and, more importantly, to channel it in particular directions, not all of which the economic theorists would unanimously approve. To understand these developments more fully, however, a bit of background is required.

American anti-trust is conducted primarily in what can be called the 
judicial mode. That is, as a general rule, anti-trust activity gets underway when a plaintiff files a lawsuit against a defendant. The suit is tried before a federal district judge and, with increasing frequency, a lay jury. The judge is not a specialist in anti-trust matters; indeed he or she may see an anti-trust case quite infrequently (depending on the district) sandwiched in among drug smuggling, bank robbery, and kidnapping cases. The jury is even less likely to be knowledgeable about economics or anti-trust, with university education the exception rather than the norm.

Anti-trust defendants are typically business corporations, but trade associations (e.g. The New York Stock Exchange), professional organisations (e.g. The American Medical Association), educational associations (e.g. The National Collegiate Athletic Association), non-commercial entities (e.g. The National Association for the Advancement of Colored People), and even cities (e.g. Boulder, Colorado), have been cast in the role of anti-trust defendant.

The plaintiff in an American anti-trust case may be the Federal Government (both the Department of Justice and the Federal Trade Commission have jurisdiction to enforce the anti-trust laws; Congress, which believed in competition in the market place, also advocated competition to enforce the anti-trust laws) or a state government suing on behalf of injured consumers within the state. But by far the overwhelming number of anti-trust cases are filed either by individual competitors (e.g. a doctor who is denied hospital operating privileges) or business entities.

The numerosity and nature of non-governmental plaintiffs is important (the Federal Government is typically a plaintiff in less than 10 per cent of cases filed in Federal Court during a given year), since it suggests that the attitude of the Justice Department, however strongly committed to economic analysis as the organising principle of anti-trust and to economic efficiency as the goal, has at best only an indirect influence on the bulk of anti-trust activity. Private plaintiffs need be motivated by nothing more than financial gain, and the judiciary is under no obligation, in the absence of new legislation, to mimic the enforcement philosophy of a particular administration.

Indeed, a dominant characteristic of the Federal Judiciary, in the ninetyfive years since the passage of the Sherman Act, has been a pronounced reluctance to undertake any kind of substantive economic analysis in antitrust cases, preferring to decide cases with simple rules of thumb that enable judges to categorise behaviour as lawful or unlawful. This theme was sounded in the first substantive case to reach the Supreme Court in an antitrust matter, United States v Trans-Missouri Freight Association 166 US 290 (1897), where the Court refused to consider a defence argument that the prices fixed by the cartel were no more than a reasonable level and that, in any event, the higher prices were necessary for the long-term survival of the railroad industry. The Court asserted its lack of expertise to consider such questions, holding that any price fixing agreement was unlawful under the 


\section{Fiscal Studies}

statute. Eventually, this mentality was crystallised in the per se rule for price fixing.

The per se rule for price fixing is, however, merely the most obvious illustration of the judiciary's preference for simple rules of thumb and its aversion to substantive economic analysis. Per se rules have governed other areas as well, such as tie-ins and group boycotts, ${ }^{2}$ and even where no per se rule applies, such as in merger cases, similarly simple rules (e.g. based on market shares) are utilised.

\section{THE ASYMMETRICAL ADOPTION OF ECONOMIC THEORY}

Surprisingly, the result of the judicial aversion to doing substantive economic analysis is not that the courts always resist arguments based on economics. Rather, the judicial response to the call for increased reliance on economic analysis will depend critically on the nature of the analysis required. Courts will incorporate the teachings of economic theory where those teachings can be transformed into pigeon holes or simple rules. Where the relevant economic advice would require the judge to perform economic analysis, however, that advice is likely to be ignored. This point can be illustrated by reference to two areas of recent activity in American anti-trust - the law on monopolisation, especially with regard to so-called predatory pricing, and the law on vertical restraints, especially vertical price fixing or resale price maintenance.

\section{Predatory Pricing and Monopolisation}

Going into 1975 the American case-law on monopolisation was in an unsatisfactory state. Courts seemed torn between the desire to find a firm which enjoyed a dominant position guilty per se of monopolisation, and the perceived need to point to some specific conduct that could be labelled 'culpable' before unlawful monopolisation could be found. The unhappy result seemed to be that virtually any action taken by a large firm to maintain or increase its market share was labelled 'exclusionary conduct' and satisfied the behavioural requirement for unlawful monopoly. This meant that once a firm achieved a significant market share, almost nothing (short of rapidly yielding the monopoly position) could be done to avoid a Sherman Act violation. Included in the category of condemned conduct were price cuts, since such cuts, when undertaken by a dominant firm, were likely to facilitate the continuation of that dominance (at least in the sense of maintaining a high market share), even if the price cuts were the quite natural business

\footnotetext{
${ }^{2}$ There are established exceptions to the per se rule in some circumstances, e.g. for certain self-regulation activities by professional organisations such as the American Medical Association, but until quite recently the rule was sufficiently well entrenched to permit the generalisation made in this article. For a discussion of how the per se rule has been applied with less rigidity in the past year or two, see Easterbrook (1984).
} 
reaction to the low prices of a new entrant or a heretofore unaggressive rival. 'Predatory pricing' was the label given to such price cuts by the dominant firm and it was a label that meant almost certain conviction.

While the case-law could be criticised by economists as destroying the incentive for firms that had achieved a large share by producing good products and offering them to consumers at low prices to continue this seemingly desirable conduct, arguably the result could be tolerated so long as it was confined to the occasional industry giant, since a case could be made that the economy would be well served by dissolving the monopolist's power regardless of how it had behaved. In addition the Justice Department could be counted on to use its prosecutorial discretion to avoid attacking the truly benificent large firm.

However, by the mid-1970s, the Justice Department had no monopoly on anti-monopoly cases. Increasingly, the plaintiff in a Sherman Act case was not the government, but a competitor of the large firm, and prosecutorial discretion was replaced by the motto 'Sue first - analyse later', in the hope that, regardless of the merits of the case, the large firm could be induced to make a substantial financial settlement to avoid the risk of an adverse judgement (which carried with it mandatory treble damages). Moreover, the defendants were no longer only the well-known industrial giants, but virtually any firm that had achieved a strong position, even in a 'market' that was narrowly defined and small by absolute standards. In short, monopoly litigation was out of control. Courts were swamped with cases, often against small defendants accused of charging low prices. It would no longer do to find all such firms guilty of monopolisation, yet the case-law seemed to offer no principled way of sorting out the good from the bad.

Then in 1975 Harvard Law Professors Phillip Areeda and Donald Turner published a law review article ${ }^{3}$ in which they proposed a remarkably simple (it seemed at the time) solution to the predatory pricing morass. Price cuts by a dominant firm would be presumed lawful so long as the resulting price level exceeded the firm's incremental costs of production. This would be true without regard to the impact of the price cuts on the market share of the dominant firm or on the viability of smaller rivals. Moreover, internal memoranda suggesting that certain employees of the dominant firm desired to kill off its rivals would do nothing to alter the presumption of legality, thus saving the court from having to interpret the corporate 'intent' from dozens of such memoranda.

The approach taken in the article conformed perfectly with the court's preference for simple rules of thumb. Other than defining the market and measuring market share, the only issue was whether price was below cost. Moreover, since the latter condition would rarely be satisfied, cases could

\footnotetext{
${ }^{3}$ Areeda and Turner (1975).
} 


\section{Fiscal Studies}

often be disposed of without conclusions on either relevant market or market share.

The impact of the article was rapid and dramatic. Within months, the article was being cited as support for dismissing cases and, over the several years following, defendants were successful in the overwhelming number of decisions that cited the article. ${ }^{4}$ Indeed, frequently cases were disposed of solely on the pleadings. The present article does not necessarily argue that the development was a desirable one, or that the economic analysis that underlay the Areeda-Turner rules was correct. (I come back to that point a bit later.) The episode is notable because it represents a circumstance in which the courts responded rapidly and enthusiastically to the advice of economists. Economics was influential because the relevant advice, rightly or wrongly, could be compressed into simple rules of thumb. ${ }^{5}$

\section{Vertical Restraints}

As in the case of predatory pricing, the pre-1975 case-law on vertical restraints $^{6}$ was the subject of extensive discussion and criticism from economists.' Yet the literature, while acknowledged by courts in opinions on the subject, was not nearly so successful in influencing the development of the case-law.

No doubt, many factors can be cited that may have contributed to the result, but at least two are consistent with the theme of this article. First, the existing law was relatively simple. Based on the alleged common law prohibition of restraint on alienation, the law, with few exceptions, ${ }^{8}$ held all vertical restraints unlawful per se. Surely nothing could be more convenient from the perspective of a judiciary averse to conducting extensive economic analysis.

Second, the specific advice explicit or implicit in the economics literature on vertical restraints seemed not readily amenable to simple rules. Economists had theorised that a manufacturer might need to restrict price competition among its retail dealers in order to induce dealers to undertake costly promotional activities that would substantially increase the overall demand for the product. (Even though the retail price might be higher as a

\footnotetext{
+ See Hurwitz and Kovacic (1982).

${ }^{5}$ An important additional factor at work was the absence of any alternative simple rules.

${ }^{6}$ For a detailed discussion of the history of vertical restraints in the American courts, see Hay (1985).

The criticism dates at least to 1960 . See Telser (1960).

- Situations where the goods were given to the retailer under a consignment arrangement were treated more favourably. In addition, a manufacturer could choose unilaterally not to deal with certain retailers (e.g. price cutters), so long as no agreement could be implied between the manufacturer and dealers that followed the manufacturer's wishes. See Hay (1985).
} 
result, the positive demand-generating effect of this promotional activity would more than offset the reduction in sales from the higher retail prices.) Hence vertical restraints could actually improve the attractiveness of the product in the minds of consumers and thereby could be said to improve competition among manufacturers even though it restricted competition among retailers of the individual manufacturer.

Unfortunately, the literature, while demonstrating that vertical restraints could improve competition and promote economic efficiency, did not, with few exceptions, argue that improved efficiency was the only possible result. For example, vertical restraints might reduce competition if they facilitated collusion among competing manufacturers. The courts were given no clear guidelines on when vertical restraints would turn out to improve consumers' welfare, and when they would worsen it. Thus, if the courts were to take economic advice seriously, they apparently would be required to ascertain the net impact of the vertical restraint in each instance, necessitating the kind of extensive economic analysis they were reluctant to undertake.

The result, not surprisingly, was that courts ignored the economics literature entirely for a time and, even when the literature began to be cited, the analysis was either disregarded when it came to fashioning the rules or used to justify distinctions that did not flow logically from the relevant economic analysis. Thus, at present, the law distinguishes outright price restraints, i.e. resale price maintenance, from non-price restraints, such as allocating exclusive territories among retail distributors. ${ }^{9}$ Such distinctions have the nice pigeon hole character that courts prefer, but would not find support in much of the relevant economics literature, including that cited by the courts. As a consequence of the disparate treatment given the two kinds of restraints, litigation focuses not on the competitive impact but instead on the distinction, with plaintiff attempting to characterise facially non-price restraints as in fact price restraints. ${ }^{10}$

Overall, then, economic theory would be judged less influential in affecting the development of the case-law on vertical restraints. For a time the economics literature was ignored entirely, and then cited in support of rules that did not flow logically from the economists' analyses. A primary reason for this result was, in my opinion, the fact that the relevant economics placed too much of a burden on the courts to sort out good restraints from bad. Until the economic advice can be compressed (perhaps with some acceptable

\footnotetext{
- The former is illegal per se. The latter is subject to rule of reason analysis since the decision in GTE Sylvania Inc v Continental TV Inc 433 US 36 (1977). The opinion in Sylvania gave lower courts no clear guidance about how a rule of reason inquiry should be undertaken. As a consequence, most non-price restraints have been upheld.

${ }^{10}$ This was a main issue in the recent case Monsanto Co v Spray-Rite Service Corp 104 S.Ct. 1464 (1984). In its opinion, the Court acknowledged the difficulty of distinguishing price and non-price restraints, but insisted that lower courts continue to make the distinction.
} 


\section{Fiscal Studies}

level of distortion) into simple rules of thumb or pigeon holes ${ }^{11}$ it is not likely to dominate the judicial analysis in the way the literature on predatory pricing succeeded in doing.

To summarise the argument thus far, it is not necessarily the case that courts will resist the teachings of economists in formulating decisions on antitrust cases. However, economics is likely to be influential only if it can be compressed into relatively simple rules of thumb. More complex economic analysis is likely to be ignored entirely or to be so distorted in its adaptation to legal rules that the results may be no better than had economics been left out of the picture entirely.

\section{Merger Policy}

The point can be illustrated further with reference to merger policy in the United States. As in the case of predatory pricing, economists have had a dramatic impact, but, unlike predatory pricing, the relevant economics is not simple and does not take the form of simple yes or no rules. The 1984 Department of Justice Merger Guidelines require very sophisticated quantitative judgements in the process of defining relevant product and geographic markets and in attributing to firms some measure of market strength. ${ }^{2}$ In addition, the possible negative effects from increased concentration in a properly defined market are to be weighed against possible efficiencies that might be gained from the merger in order to determine the net impact on economic efficiency.

Yet despite these complexities, the relevant economics achieved virtually instantaneous implementation. ${ }^{13}$ The reason, as suggested by the label 'Department of Justice Guidelines', is that, as a practical matter, merger policy in the United States is not carried out in the judicial mode. All mergers of consequence must be notified in advance to the Justice Department ${ }^{14}$ and if the Department elects to challenge the merger in court and so notifies the parties concerned, nine times out of ten the contemplated merger will be abandoned. Perhaps equally importantly, all the possible mergers that are seen by the potential parties to the merger to be in clear violation of the

\footnotetext{
"A possible candidate for a workable rule would focus on market share and immunise all vertical restraints (price and non-price) for firms with shares small enough to make it unlikely that they enjoy any significant market power.

${ }^{12}$ For a description of how the Guidelines work, see Hay and Reynolds (1985).

${ }^{13}$ The Guidelines were initially issued in 1982 , and implemented immediately. The 1984 Guidelines reflect fairly modest revisions of the 1982 version.

14 The Federal Trade Commission has concurrent jurisdiction over mergers and receives the same notification. The FTC has not issued any detailed guidelines, but its announced enforcement policy does not suggest strong differences in the way it would analyse mergers, and in the two years since the 1982 Guidelines, few operative differences have been observed.
} 
Guidelines will not even reach the stage of notification, but will be abandoned at the planning stage. Thus, for all intents and purposes, merger policy is made not in the adversarial atmosphere of the courtroom, but unilaterally by the Justice Department in announcing in advance what mergers it will attempt to block. Hence, even though the relevant economic analysis is complex, complexity has not been a bar to rapid implementation. The Justice Department has a large staff of highly trained economists serving alongside lawyers who by now have considerable sophistication themselves in the use of economics. The relevant advice need not be compressed into simple rules.

\section{CONCLUSIONS}

A possible conclusion from this contrast between merger policy and both predatory pricing and vertical restraints is that, at least where the relevant economic analysis is likely to be complex and not easily compressed into simple rules, policy is best made outside the judicial arena, perhaps, as in the case of US merger policy, by an executive agency acting unilaterally or, as, for example, in the case of the UK Monopolies and Mergers Commission, by an expert body operating in an administrative or quasi-administrative fashion (depending upon the extent of adversarial input, e.g. cross-examination of expert witnesses, that will be permitted). Indeed, it might be concluded that general-purpose courts should play no role at all in anti-trust, since, even where the relevant economics could be compressed into simple rules, the expert agency could accomplish the same result, perhaps more rapidly, and with less opportunity for confusion.

However, the same examples used in this paper to support the argument that courts are not the ideal forum for incorporating sophisticated economic analysis can be used to illustrate that removal of anti-trust altogether from the judicial mode carries with it certain risks that may warrant serious consideration. It will be recalled that, in relating the rapid adoption by the courts of the Areeda-Turner rule on predatory pricing, I did not indicate agreement with the Areeda-Turner analysis or approval of the resulting rules. As it turned out many commentators did not agree with their analysis and in the wake of the publication of their article, a virtual tidal wave of literature emerged, criticising the Areeda-Turner analysis, condemning the proposed rules, and offering alternatives. In addition, as courts attempted to implement the rule in various factual circumstances, other defects or at least ambiguities were noted. ${ }^{15}$

Since the Supreme Court had not yet blessed the Areeda-Turner analysis, there was ample opportunity for a kind of judicial experimentation with

\footnotetext{
${ }^{15}$ For a discussion of these developments, see Brodley and Hay (1981).
} 


\section{Fiscal Studies}

predatory pricing rules as individual courts in dozens of subsequent cases could react both to earlier courts' efforts to apply the rules and to literature that emerged in the interim. As a result, while the original economic analysis has not been abandoned - indeed it is still at the core of most judicial opinions - there has been an evolution of the original rule into a number of sophisticated variants that attempt to correct for the perceived deficiencies in the original. Interestingly, despite the passing of ten years time, the Supreme Court has not yet accepted certiorari in (i.e. agreed to review) a predatory pricing case. Perhaps this is merely chance, but one is tempted to ask if it is a deliberate strategy undertaken in order to benefit from the ongoing period of experimentation. When the Court ultimately takes a case, it will have the benefit of dozens of learned articles and perhaps as many as a hundred district and appellate court opinions as a base to work from. There is at least a hope that the analysis and the rules that subsequently emerge will reflect this opportunity for learning.

In contrast, the Merger Guidelines do not permit the same degree of experimentation. For one thing, if the analytical underpinnings of the Justice Department procedures are reflective of a particular political or economic philosophy that is not universally well regarded, that underlying philosophy is likely to be impervious to academic criticism. Moreover, virtually all relevant decisions are made in one place, and while the Justice Department may elect unilaterally to alter its analysis in the wake of unsatisfactory efforts to apply the Guidelines to previously unanticipated fact patterns or to react to economic commentary, ${ }^{16}$ there is still less opportunity for experimentation than where there are hundreds of different decision makers, as in the Federal Judiciary.

I wish to emphasise, however, that the comments about the Guidelines are meant to reflect the potential for problems in this kind of decision mode, not any actual dissatisfaction with the present Guidelines. Nor do I wish to minimise the inefficiency that has resulted from US courts' clumsy and erratic efforts to incorporate economics into the decision process. The point is simply that where policy rests on an analytic base that does not reflect consensus or, like any science, is continually evolving (often quite rapidly), the judicial mode provides an opportunity for distillation, adjustment, and, if necessary, reversal of previously well-established positions in the light of new evidence, and for a diversity of decision making until consensus is achieved. This is a factor that ought to be given some weight in decisions as to how best to structure the decision making framework of competition policy.

\footnotetext{
${ }^{16}$ As indicated above, the 1982 Guidelines were revised after two years experience.
} 


\section{REFERENCES}

Areeda, P. and Turner, D. (1975), 'Predatory pricing and related practices under Section 2 of the Sherman Act', Harvard Law Review, vol.88.

Brodley, J. and Hay, G. (1981), 'Predatory pricing: competing economic theories and the evolution of legal doctrine', Cornell Law Review, vol.66.

Easterbrook, F. (1984), 'The limits of antitrust', Texas Law Review, vol.63.

Hay, G. (1984), 'Pigeonholes in antitrust', Antitrust Bulletin, vol.29.

Hay, G. (1985), 'Vertical restraints after Monsanto', Cornell Law Review, forthcoming.

Hay, G. and Reynolds, R. (1985), 'Competition and antitrust in the petroleum industry: an application of the Merger Guidelines' in F. Fisher (ed) Essays in Industrial Organisation, forthcoming.

Hurwitz, J. and Kovacic, W. (1982), 'Judicial analysis of predation: the emerging trends', Vanderbilt Law Review, vol.63.

Telser, L. (1960), 'Why should manufacturers want fair trade?', Journal of Law and Economics, vol.3. 